\title{
Synthesis of Lithiophorite in High Alkaline Conditions
}

\author{
Deng-Shiu Yang ${ }^{\mathrm{a}, \mathrm{b}}$ (楊登旭), Ming-Kuang Wang * (王明光), Chia-Ming Chang ( 張家銘), \\ Hwo-Shuenn Sheu ${ }^{\mathrm{d}}$ (許火順) and Bing-Joe Hwang ${ }^{\mathrm{e}}$ ( 黃炳照 ) \\ anstitute of Agricultural Chemistry, National Taiwan University, Taipei 106, Taiwan, R.O.C. \\ ${ }^{\mathrm{b}}$ Fortune Institute of Technology, Kaohsiung County 831, Taiwan, R.O.C. \\ ${ }^{\mathrm{c}}$ Department of Soil Environmental Science, National Chung Hsing University, \\ Taichung 402, Taiwan, R.O.C. \\ ${ }^{\mathrm{d}}$ Synchrotron Radiation Research Center, Hsinchu 300, Taiwan, R.O.C. \\ ${ }^{\mathrm{e}}$ Department of Chemical Engineering, Taiwan University of Science and Technology, \\ Taipei 106, Taiwan, R.O.C.
}

\begin{abstract}
Lithiophorite consists of alternatively stacked $\mathrm{MnO}_{6}$ octahedral sheets and $\mathrm{LiAl}_{2}(\mathrm{OH})_{6}$ octahedral sheets. Its applications in laboratories and industries have been hindered by sophisticated operation procedures, long reaction time, or impurities existing in the final product. We proposed a fast and simple method, mixing birnessite, aluminate and lithium hydroxide together (designated it as the BAL method) in high alkaline conditions ( $\mathrm{pH}>13$ ), and treating it hydrothermally at $423 \mathrm{~K}$ for 6 hours to prepare pure lithiophorite. A specific reaction between lithium cations and aluminate anions plays as a key role in the BAL method. Due to this specific reaction, $\mathrm{Li}_{\mathrm{x}} \mathrm{Al}_{\mathrm{n}}(\mathrm{OH})_{\mathrm{m}}{ }^{+\mathrm{z}}$ complexed cations can form and penetrate into interlayers of birnessite to replace sodium cations. In high alkaline conditions $(\mathrm{pH}>12), \mathrm{Li}_{\mathrm{x}} \mathrm{Al}_{\mathrm{n}}(\mathrm{OH})_{\mathrm{m}}{ }^{{ }^{2} \mathrm{z}}$ complexed cations become smaller and are soluble. Thus, the higher alkaline $\mathrm{Li}_{\mathrm{x}} \mathrm{Al}_{\mathrm{n}}(\mathrm{OH})_{\mathrm{m}}{ }^{+\mathrm{z}}$ complexed cations can penetrate into interlayers of birnessite at a higher rate. Furthermore, impurities, such as lithium intercalated gibbsite (LIG), aluminum oxyhydroxides and aluminum hydroxides are not stable in high alkaline conditions. Consequently, pure lithiophorite can be easily obtained within 6 hours in high alkaline conditions.
\end{abstract}

Keywords: Alkaline conditions; Birnessite; Lithiophorite; LIG; Phyllomanganate.

\section{INTRODUCTION}

Lithiophorite, with ideal formula ${ }^{1} \mathrm{LiAl}_{2}(\mathrm{OH})_{6} \mathrm{Mn}_{3} \mathrm{O}_{6}$, is a naturally occurring phyllomanganate. Its structure consists of alternately stacked $\mathrm{LiAl}_{2}(\mathrm{OH})_{6}$ octahedral sheets and $\mathrm{MnO}_{6}$ octahedral sheets. A previous single-crystal X-ray diffraction study ${ }^{2}$ of lithiophorite revealed that the structure is trigonal $(R \overline{3} m)$ with unit-cell parameters $a=2.9247 \AA, c=$ $28.169 \AA$. Reports related to applications of lithiophorite are rare; however, the two-dimensional structure of lithiophorite may endow it with novel low-dimensional magnetic, electron-conducting and ion-conducting behavior similar to manganese oxides with layered-perovskite structure ${ }^{3,4}$ or layered $\mathrm{LiMnO}_{2}{ }^{5,6}$

Although applications of lithiophorite to the magnetic or electronic industries may be promising, the lack of an easy and reliable route to lithiophorite has hindered our understanding of this compound. In 1950 , Wadsley ${ }^{7}$ presented the first method to prepare lithiophorite, but the only information it offered was: "The aluminum-lithium derivative was readily re-crystallized by heating at $433 \mathrm{~K}$ for three weeks in a solution containing $1 \%$ each of lithium chloride and aluminum chloride." In 1973, Giovanoli et al. ${ }^{8}$ described more details of their method to synthesize lithiophorite. They mixed gibbsite, $\mathrm{H}^{+}$-exchanged birnessite $\left(\mathrm{Mn}_{7} \mathrm{O}_{13} \cdot 5 \mathrm{H}_{2} \mathrm{O}\right)$ and lithium hydroxide hydrate together and subsequently treated this admixture at $573 \mathrm{~K}$ for 48 hours. As described by the authors, a run with $20 \% \mathrm{Mn}$ excess happened to yield almost pure lithiophorite, but it was not reproducible. Some impurities, $\gamma$-AlOOH or other unidentified compounds, were found in their products. Recently, Feng et al. ${ }^{9}$ proposed a mechanism of lithiophorite formation based on a lithium-aluminum hydroxide complex ion-exchange process. They conducted the lithium-aluminum hydroxide complex ion-exchange under a $\mathrm{pH}$ of around 4. As they described, ${ }^{9}$ precipitation formed in the period of preparing lithium-aluminum hydroxide com-

\footnotetext{
* Corresponding author. Tel: (0118862)23630231 ext. 2491 or 3066; fax: (0118862)2366-0751; e-mail: mkwang@ccms.ntu.edu.tw
} 
plex cations. This may be a disadvantage in preparing lithiophorite for practical applications.

In this study, we aim to present a fast and simple method to synthesize lithiophorite. This method, conducted under high alkaline conditions, was built up on the basis of adopting birnessite as a precursor and utilizing a specific reaction between aqueous solutions of lithium cations and aluminate anions $\left[\mathrm{Al}(\mathrm{OH})_{4}{ }^{-}\right]$. We will demonstrate what advantages our method has and try to explain the reasons in this study.

\section{EXPERIMENTAL SECTION}

\section{Synthesis of Birnessite}

The first component of our method to prepare lithiophorite is birnessite. It was synthesized by the oxidationdeprotonation reaction (ODPR) method developed recently. ${ }^{10}$ This procedure began with dissolving $11 \mathrm{gm}$ of manganese chips in $\mathrm{HClO}_{4}$ solution $\left(50 \mathrm{~mL} 12 \mathrm{M} \mathrm{HClO}_{4}+300 \mathrm{~mL}\right.$ DDW). After all manganese chips were dissolved, these $\mathrm{Mn}^{+2}$ solutions were mixed with $150 \mathrm{~mL}$ saturated $\mathrm{NaOH}$ (about 19.2 M) under purging nitrogen gas constantly. $\mathrm{A} \mathrm{Mn}^{+3}$-free pyrochroite $\left[\mathrm{Mn}(\mathrm{OH})_{2}\right]$ suspension was thus formed. Oxygen gas, with a rate of $3 \mathrm{~L} \mathrm{~min}^{-1}$ through a porous Teflon tube and with vigorous stirring, instead of nitrogen gas, was purged into this pyrochroite suspension to proceed oxidation as soon as the temperature of this suspension was cooled down to 273 $\mathrm{K}$. A black birnessite suspension was obtained after oxidation was carried on for 5 hours.

\section{Synthesis of Lithiophorite}

The birnessite-aluminate-lithium hydroxide (BAL) method was adopted to prepare lithiophorite. In this method, birnessite was a precursor. It was reacted with aluminate and lithium hydroxide, under hydrothermal treatment, to form lithiophorite in high alkaline conditions. Because the ideal formula of lithiophorite ${ }^{1}$ is $\mathrm{LiAl}_{2}(\mathrm{OH})_{6} \mathrm{Mn}_{3} \mathrm{O}_{6}$, the molar ratio of $\mathrm{Mn}$ to $\mathrm{Al}$ was set at 3 to $2.150 \mathrm{~mL}$ of birnessite suspension containing about 0.075 mole manganese was continuously washed and centrifuged 4 times to remove excess alkaline and salts. The precipitation obtained was re-suspended in $300 \mathrm{~mL}$ 0.1 M LiOH. This LiOH-birnessite suspension was mixed thoroughly with $17 \mathrm{~mL} 3 \mathrm{M} \mathrm{NaAl}(\mathrm{OH})_{4}$ [81 gm of aluminum chips reacted with $480 \mathrm{gm}$ of $\mathrm{NaOH}$, and diluted to $1000 \mathrm{~mL}$ ] in a Teflon container. This suspension was then treated by hydrothermal treatment at $423 \mathrm{~K}$ for 6 hours. The hydrothermal product was washed and centrifuged 5 times before being freeze-dried and kept for further instrumental measurements.

\section{X-ray Diffraction (XRD) Studies}

X-ray diffraction and the Retvield method were adopted to identify the hydrothermal product of the BAL method. $\mathrm{X}$-ray source is generated by synchrotron radiation at the Synchrotron Radiation Research Center (SRRC) in Hsinchu, Taiwan with storage ring operating at the energy of $1.51 \mathrm{GeV}$ and injection current of about $200 \mathrm{~mA}$. The wavelength of $\mathrm{X}$-ray is $1.32633 \AA$. The step scan rate was $10 \mathrm{~s} / \mathrm{step}$ and step size was $0.02^{\circ}(2 \theta)$. In order to reduce the effect of preferred orientation, the sample was mounted by top loading, instead of conventional loading. Adopting single-crystal data of lithiophorite $^{2}$ as a model, the X-ray diffraction data were fitted with the General Structure Analysis System (GSAS) program of the Retvield method.

\section{Scanning Electronic Microscope (SEM)}

The SEM images were obtained with a Hitachi Model S-800 Field Emission SEM. The acceleration potential was $20 \mathrm{kV}$.

\section{Infrared Spectrophotometric (IR) Analysis}

Transmission IR spectra were obtained with a Bomem model DA8.3. Middle IR spectra, from $4000 \mathrm{~cm}^{-1}$ to $500 \mathrm{~cm}^{-1}$, were recorded in this work. Resolution of all spectra was 2 $\mathrm{cm}^{-1}$. Sample-KBr mixtures of $200 \mathrm{mg}$ (proper sample/KBr ratio is in the range of $1 / 400$ to $1 / 200$ ) were pressed to form a pellet of $13 \mathrm{~mm}$ in diameter. IR spectra were recorded with a mercury cadmium telluride (MCT) detector. The number of scans was 400 times. Nitrogen gas was purged into the sample chamber during the scanning period.

\section{Titrating Aluminate}

In order to study the relationship between lithium cations and aluminate anions, titration experiments of aluminate were conducted by a Mettler DL25 titrator. $50 \mathrm{~mL}$ of $0.5 \mathrm{M}$ $\mathrm{NaAl}(\mathrm{OH})_{4}$ [dissolved $13.5 \mathrm{~g}$ aluminum chips in $40 \mathrm{~g} \mathrm{NaOH}$, and then diluted to $1000 \mathrm{~mL}$ ] was contained in a polypropylene cup. It was titrated by three titrants $-1.8 \mathrm{M} \mathrm{HCl}, 1.8 \mathrm{M}$ $\mathrm{HCl}+1 \mathrm{M} \mathrm{LiCl}$ and $1.8 \mathrm{M} \mathrm{HCl}+1 \mathrm{M} \mathrm{NaCl}$, respectively.

\section{RESULTS AND DISCUSSION}

\section{Synthesis and Identification}

After the high alkaline $(\mathrm{pH}>13)$ birnessite-aluminatelithium hydroxide admixture was hydrothermally treated for 6 hours, fine black powder was obtained. Under SEM investigation, the freeze-dried fine black powder is composed of sub-micron platy particles (Fig. 1a). To identify this black 
powder, its X-ray diffraction data were fitted with a GSAS program and single-crystal data of lithiophorite. ${ }^{2}$ The crystal structure of the black powder can be described by a trigonal $(R \overline{3} m)$ with unit-cell parameters $a=2.9092 \AA, c=28.265 \AA$. Low values of $\chi^{2}, \mathrm{R}_{\mathrm{wp}}$ and $\mathrm{R}_{\mathrm{p}}(1.029,4.51 \%$ and $3.04 \%$, respectively) and good fitting between calculating and observed patterns (Fig. 2) indicate that lithiophorite is the only phase in the powder prepared from the BAL method. Moreover, compared with XRD patterns of previous reports ${ }^{8,9}$ and JCPDS (No. 16-364), all reflections in Fig. 2 can be attributed

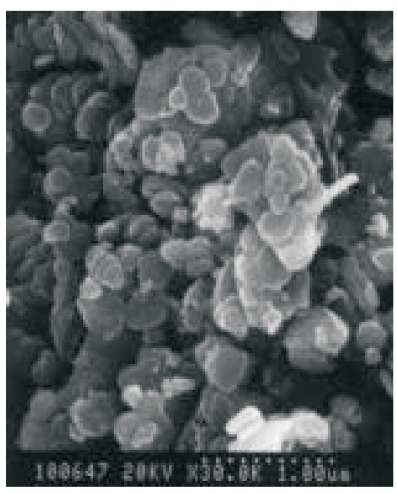

(a)

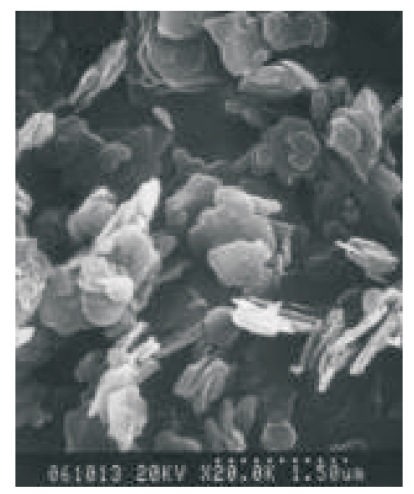

(b)
Fig. 1. (a) An SEM photograph of lithiophorite particles prepared by the BAL route. (b) An SEM photograph of LIG particles collected from the experiment of $\mathrm{HCL}+\mathrm{Li}$ titrated aluminate.

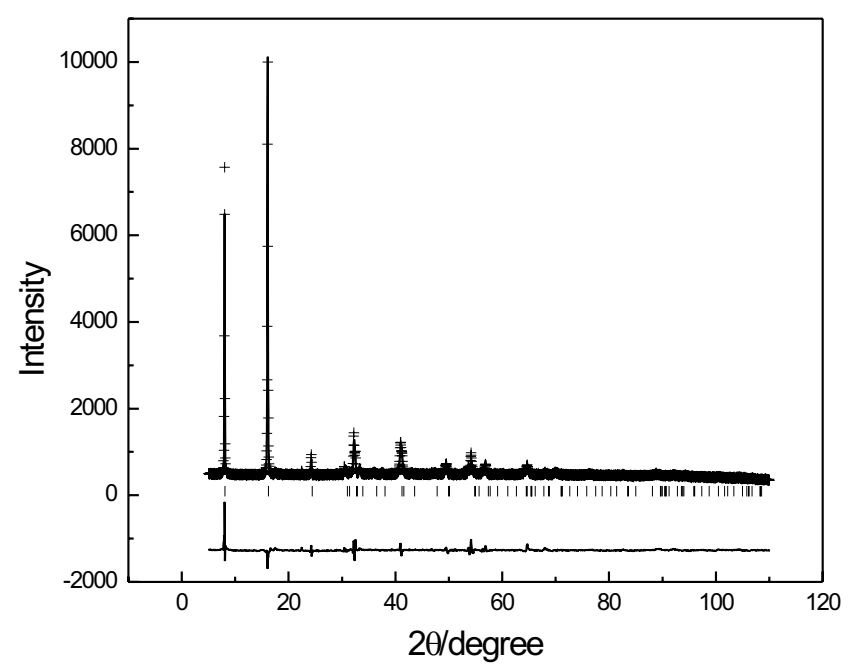

Fig. 2. Final Rietveld fit for the X-ray diffraction pattern of lithiophorite: crosses represent observed data; the upper solid line is the calculated pattern; the lower solid line is the difference profile. Sticks between two solid lines are the calculated X-ray reflections of lithiophorite. to lithiophorite. The major peaks and their indices are: 9.55 $\AA$ (001), $4.77 \AA(002), 3.17 \AA(003), 2.37 \AA(111), 1.88 \AA(005)$. No reflections of birnessite $(7.10,3.56,2.51,2.41,2.21,2.13$, $1.86,1.81,1.63,1.48,1.43,1.41$ and $1.37 \AA)^{10}$ or lithiumintercalated gibbsite (LIG, following the nomenclature of previous researchers, ${ }^{11-16}$ which has X-ray reflections at 7.7, 4.4, 3.87 $\AA^{16}$ ) were observed.

IR spectra of birnessite, LIG and lithiophorite are shown in Fig. 3. In the spectrum of birnessite, there are no significant absorption bands except for a very broad weak band in the range of 3600 to 3000 wavenumbers. On the other hand, major absorption bands occur at 3441, 1375, 1004, 754 and 3480, 3312, 986, 694 wavenumbers in the spectrum of LIG and lithiophorite, respectively. No bands arising from birnessite or LIG are observed in the IR spectrum of lithiophorite. In other words, IR cannot detect birnessite or LIG in the lithiophorite prepared in this study.

\section{Titrating Aluminate}

The results of titration (Fig. 4) shows that two curves obtained by separately using $\mathrm{HCl}$ solution (curve 1) and $\mathrm{HCl}$ solution with $\mathrm{NaCl}$ (curve 2) to titrate aluminate solution display no distinct differences. By contrast, curve 3, obtained by using $\mathrm{HCl}$ solution with $\mathrm{LiCl}$ to titrate aluminate solution, is not similar to the previous two curves. Furthermore, it was found that white precipitation formed at a $\mathrm{pH}$ of around 12 when we used $\mathrm{HCl}$ solution with $\mathrm{LiCl}$ to titrate aluminate. SEM demonstrated that this precipitation is composed of nu-

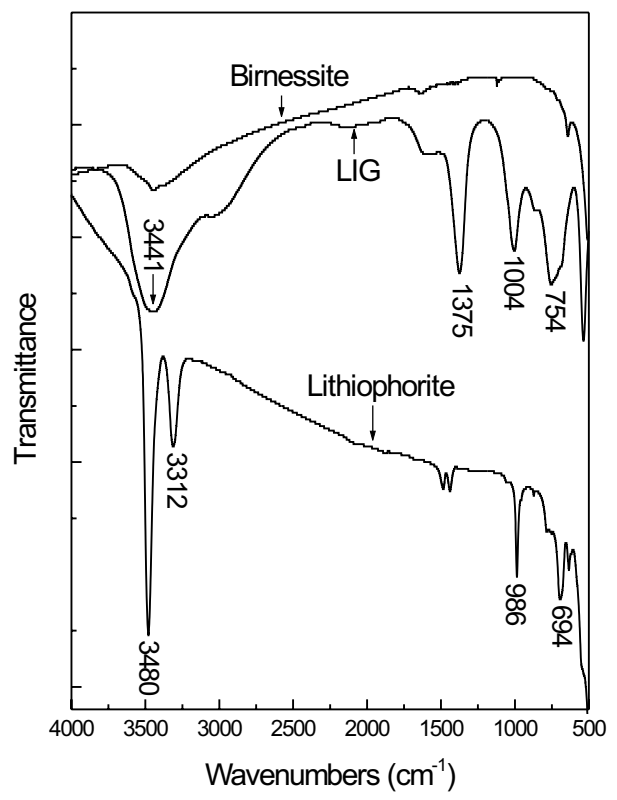

Fig. 3. Infrared spectra of birnessite, LIG and lithiophorite in the range from 4000 to $500 \mathrm{~cm}^{-1}$. 
merous tiny platy particles with diameters of hundreds of nanometers (Fig. 1b). X-ray diffraction analysis indicated that these tiny platy particles are LIG. Its prominent (001) and (002) X-ray reflections occur at $7.5 \AA$ and $3.75 \AA$, respectively. ${ }^{11-15}$

\section{Advantages of the BAL Method}

Apparently, compared with previous works, advantages of the BAL method are that it needs shorter reaction time ( 6 hours vs. days ${ }^{8,9}$ or even weeks ${ }^{7}$ ) and simpler operation procedures (admixing all components in high alkaline conditions vs. cation exchanging in around neutral conditions $^{9}$ ) to prepare pure lithiophorite. This evidence supports that lithiophorite can be prepared not only in around neutral conditions but also high alkaline conditions. It is believed that preparing lithiophorite in high alkaline conditions is one of major factors to get all these advantages mentioned above (see discussion below).

\section{A Specific Reaction between Lithium Cation and Aluminate}

A model of the formation reaction of lithiophorite (equation 1) was proposed recently. ${ }^{9}$

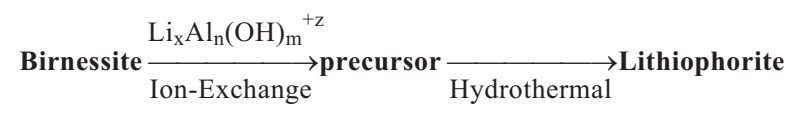

In this model, sodium cations in the interlayers of birnessite are exchanged by $\mathrm{Li}_{\mathrm{x}} \mathrm{Al}_{\mathrm{n}}(\mathrm{OH})_{\mathrm{m}}{ }^{+\mathrm{z}}$ to form a precursor of lithiophorite with $0.95-0.72 \mathrm{~nm}$ mixed layered structure. The complex cation, $\mathrm{Li}_{\mathrm{x}} \mathrm{Al}_{\mathrm{n}}(\mathrm{OH})_{\mathrm{m}}{ }^{+\mathrm{z}}$, forms because of a specific reaction between lithium cations and aluminate anions. This specific reaction can be comprehensively illus-

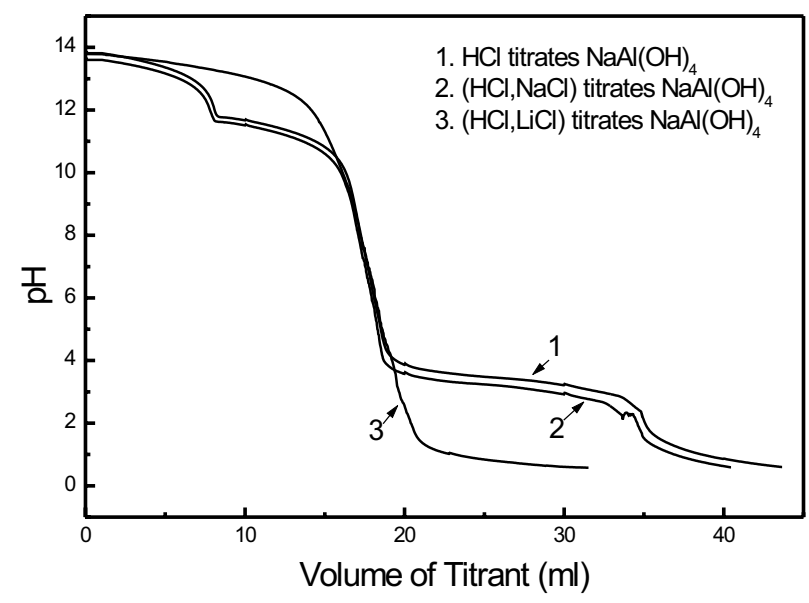

Fig. 4. Titration curves of $\mathrm{HCl}$ solutions without/with $\mathrm{NaCl}$ or $\mathrm{LiCl}$ titrating $\mathrm{NaAl}(\mathrm{OH})_{4}$. A Mettler DL25 titrator conducted this titration. trated by a simple titration experiment. The results of the titration experiment (Fig. 4), show that two curves obtained by separately using $\mathrm{HCl}$ solution (curve 1) and $\mathrm{HCl}$ solution with $\mathrm{NaCl}$ (curve 2) to titrate aluminate solution display no distinct differences. By contrast, curve 3, obtained by using $\mathrm{HCl}$ solution with $\mathrm{LiCl}$ to titrate aluminate solution, is not similar to the previous two curves. This evidence indicates that sodium cations do not influence the titration behavior of aluminate, but lithium cations do. In other words, some specific reaction occurs between lithium cations and aluminate anions, which leads to the formation of white precipitation at a $\mathrm{pH}$ of around 12 when $\mathrm{HCl}$ solution with $\mathrm{LiCl}$ was used to titrate aluminate. X-ray diffraction analysis indicated that this white precipitation is LIG. LIG is a layered double hydroxide $(\mathrm{LDH})$ with a general formula of $\left[\mathrm{LiAl}_{2}(\mathrm{OH})_{6}\right] \mathrm{X}$. $\mathrm{H}_{2} \mathrm{O}\left(\mathrm{X}=\mathrm{Cl}, \mathrm{Br}, \mathrm{NO}_{3}\right.$ and $\mathrm{OH}$ anions $) .{ }^{11-14}$ Rietveld refinement of X-ray and neutron powder diffraction patterns ${ }^{15}$ indicates that the structure of $\mathrm{LiAl}_{2}(\mathrm{OH})_{7} \cdot 2 \mathrm{H}_{2} \mathrm{O}$ is composed of $\left[\mathrm{LiAl}_{2}(\mathrm{OH})_{6}\right]^{+}$layers separated by water molecules and hydroxide ions. The structure of $\mathrm{LiAl}_{2}(\mathrm{OH})_{7} \cdot 2 \mathrm{H}_{2} \mathrm{O}$ is described as a C-centered monoclinic cell with $a=5.097 \AA, b=8.829$ $\AA, c=7.5524 \AA$, and $\beta=103.0^{\circ}$. The structure of its dehydrated form, ${ }^{11}\left[\mathrm{LiAl}_{2}(\mathrm{OH})_{6}\right] \mathrm{X}$, was determined to be hexago$\operatorname{nal}\left(\mathrm{P}_{3} / \mathrm{mcm}\right)$ with $a=5.10005 \AA, c=14.2994 \AA$. It is known that tetrahedral $\mathrm{Al}(\mathrm{OH})_{4}{ }^{-}$ions do not convert themselves into octahedral $\mathrm{Al}(\mathrm{OH})_{6}{ }^{-}$complexes until $\mathrm{pH}$ is lower than 10 . Lithium cations react with aluminate anions and change this well-known behavior. The existence of lithium cations promotes the transformation of tetrahedral $\mathrm{Al}(\mathrm{OH})_{4}{ }^{-}$into octahedral $\mathrm{Al}(\mathrm{OH})_{6}^{-3}$ at a $\mathrm{pH}$ even around 12 , and they insert themselves into octahedral vacancies in octahedral aluminum hydroxide layers to form LIG. The exact mechanism of this reaction is still unknown, even though a recent in situ X-ray diffraction study ${ }^{11}$ to monitor lithium cations intercalating themselves into gibbsite indicated that instantaneous nucleation is followed by two-dimensional diffusion of the guest anions into the host.

\section{A Model of the BAL Route}

A model of the BAL route to lithiophorite is described in equation 2 .

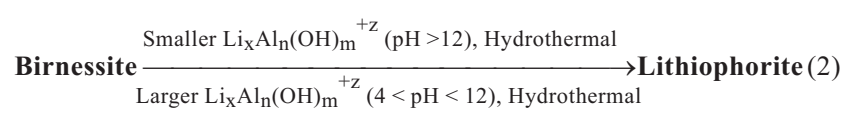

This model is generally similar to the earlier model proposed by Feng et al. ${ }^{9}$ That is, birnessite is used as a starting compound. A specific reaction between lithium cations and aluminate anions forms complex $\operatorname{Li}_{x} \mathrm{Al}_{\mathrm{n}}(\mathrm{OH})_{\mathrm{m}}{ }^{+\mathrm{z}}$ ions. These complex cations subsequently intercalate into the interlayers 
of birnessite and replace sodium cations. The major difference between the two models is lithiophorite can also be obtained by the BAL method and even at high alkaline conditions $(\mathrm{pH}>13)$. As mentioned above, $\mathrm{LIG}$ forms at a $\mathrm{pH}$ of around 12 or lower. In other words, $\mathrm{Li}_{\mathrm{x}} \mathrm{Al}_{\mathrm{n}}(\mathrm{OH})_{\mathrm{m}}{ }^{+\mathrm{z}}$ complex cations may exist in insoluble forms (namely a higher degree of polymerization / larger $n$ values) and can easily precipitate from solution when the $\mathrm{pH}$ is lower than 12 (for convenience, these $\mathrm{Li}_{\mathrm{x}} \mathrm{Al}_{\mathrm{n}}(\mathrm{OH})_{\mathrm{m}}{ }^{+\mathrm{z}}$ complex cations were designated as lower alkaline $\mathrm{Li}_{\mathrm{x}} \mathrm{Al}_{\mathrm{n}}(\mathrm{OH})_{\mathrm{m}}{ }^{+\mathrm{z}}$ complex cations). On the other hand, at high alkaline conditions $(\mathrm{pH}>12), \mathrm{Li}_{\mathrm{x}} \mathrm{Al}_{\mathrm{n}}(\mathrm{OH})_{\mathrm{m}}{ }^{+\mathrm{z}}$ complex cations (these $\mathrm{Li}_{\mathrm{x}} \mathrm{Al}_{\mathrm{n}}(\mathrm{OH})_{\mathrm{m}}{ }^{+\mathrm{z}}$ complex cations were designated as higher alkaline $\mathrm{Li}_{\mathrm{x}} \mathrm{Al}_{\mathrm{n}}(\mathrm{OH})_{\mathrm{m}}{ }^{+\mathrm{z}}$ complex cations) may exist in soluble forms (namely a lower degree of polymerization/smaller n values).

Higher solubility of the higher alkaline $\mathrm{Li}_{\mathrm{x}} \mathrm{Al}_{\mathrm{n}}(\mathrm{OH})_{\mathrm{m}}{ }^{+\mathrm{z}}$ complex cations may give our BAL method three advantages in preparing lithiophorite. The first advantage is higher reaction rate because higher alkaline $\mathrm{Li}_{\mathrm{x}} \mathrm{Al}_{\mathrm{n}}(\mathrm{OH})_{\mathrm{m}}{ }^{+\mathrm{z}}$ complex cations with smaller molecular size (cf. lower alkaline $\mathrm{Li}_{\mathrm{x}} \mathrm{Al} \mathrm{n}_{\mathrm{n}}(\mathrm{OH})_{\mathrm{m}}{ }^{+\mathrm{z}}$ complex cations) can more easily and quickly penetrate into interlayers of birnessite and replace sodium cations. The second advantage is no longer to consider the problem that any precipitation may form before proceeding cation-exchange reaction as earlier researchers did. ${ }^{9}$ The third advantage is to reduce the risk of impurities, such as LIG, aluminum hydroxides and aluminum oxyhydroxides, existing in the product because all of them are soluble in strong alkaline conditions.

It is believed these three advantages gave our BAL method shorter reaction time, simpler operation procedures,

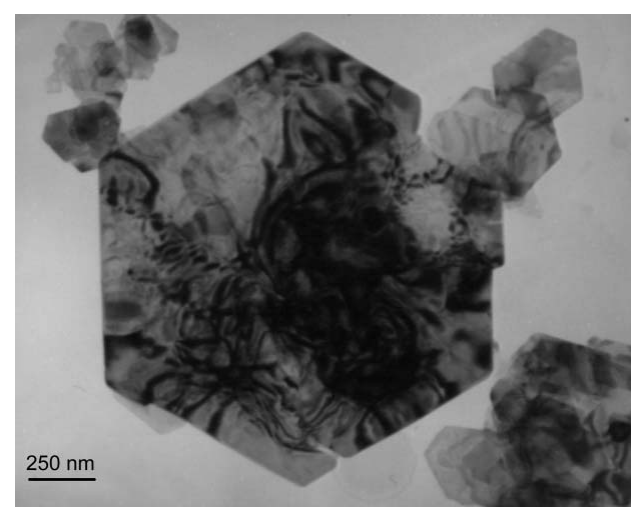

Fig. 5. A transmission electronic microscopic (TEM) photograph of lithiophorite with crystal size of micrometers and clear hexagonal outlines. This SEM image was obtained with a Hitachi Model HF-2000 Field Emission TEM. The acceleration potential was $200 \mathrm{kV}$. and produced pure lithiophorite. Because of these improvements, applications of lithiophorite in laboratories for further studies of its local structure, electronic states ${ }^{17}$ and timeresolved phase transitions ${ }^{18-20}$ are more practical than ever.

Finally, lithiophorite, with micrometer size and clear hexagonal outline (Fig. 5), was obtained in conditions similar to the BAL method presented here. It means the BAL method is a potential way to prepare lithiophorite with larger crystal size. Preparation of large single crystal lithiophorite merits further study by the BAL method.

\section{CONCLUSIONS}

The BAL method, conducted in high alkaline conditions ( $\mathrm{pH}>13$ in this study), is a fast and simple way to prepare lithiophorite. In high alkaline conditions, lithium cations react specifically with aluminate anions to form higher alkaline $\mathrm{Li}_{\mathrm{x}} \mathrm{Al}_{\mathrm{n}}(\mathrm{OH})_{\mathrm{m}}{ }^{+\mathrm{z}}$ complexed cations. Compared with lower alkaline $\mathrm{Li}_{\mathrm{x}} \mathrm{Al}_{\mathrm{n}}(\mathrm{OH})_{\mathrm{m}}{ }^{+\mathrm{z}}$ complexed cations, the molecular size of higher alkaline $\mathrm{Li}_{\mathrm{x}} \mathrm{Al}_{\mathrm{n}}(\mathrm{OH})_{\mathrm{m}}{ }^{+\mathrm{z}}$ complexed cations is smaller and thus soluble. It subsequently makes higher alkaline $\mathrm{Li}_{\mathrm{x}} \mathrm{Al}_{\mathrm{n}}(\mathrm{OH})_{\mathrm{m}}{ }^{+\mathrm{z}}$ complexed cations penetrate into interlayers of birnessite and replace sodium cations at a higher rate. Furthermore, impurities, such as LIG, aluminum oxyhydroxides and aluminum hydroxides are not stable in high alkaline conditions. Consequently, by the BAL method operating in high alkaline conditions, pure lithiophorite can be easily obtained within 6 hours.

\section{ACKNOWLEDGMENTS}

This work was financially supported by the National Science Council, ROC, under project \#NSC90-2313-B-002279.

Received November 19, 2002.

\section{REFERENCES}

1. Pauling, L.; Kamb, B. American Mineralogist 1982, 67, 817-821.

2. Post, J. E.; Appleman, D. E. American Mineralogist 1994 , 79, 370-374.

3. Moritomo, Y.; Asamitsu, A.; Kuwahara, H.; Tokura, Y. Nature 1996, 380, 141-144. 
4. Perring, T. G.; Aeppli, G.; Kimura, T.; Tokura, Y.; Adams, M. A. Physical Review B 1998, 58(22), R14693-R14696.

5. Hwang, S.-J.; Park, H.-S.; Choy, J.-H. Chemistry of Materials 2000, 12, 1818-1826.

6. Thackeray, M. M. Journal of Electrochemical Society 1995 , 142, 2558-2563.

7. Wadsley, A. D. American Mineralogist 1950, 35, 485-499.

8. Giovanoli, R.; Buhler, H.; Sokolowska, K. Journal de Microscopie 1973, 18, 271-284.

9. Feng, Q.; Honbu, C.; Yanagisawa, K.; Yamasaki, N. Chemistry of Materials 1999, 11, 2444-2450.

10. Yang, D. S.; Wang, M. K. Chemistry of Materials 2001, 13, 2589-2594.

11. Fogg, A. M.; O'Hare, D. Chemistry of Materials 1999, 11, 1771-1775.

12. Besserguenev, A. V.; Fogg, A. M.; Francis, R. J.; Price, S. J.; O'Hare, D. Chemistry of Materials 1997, 9, 241-247.
13. Frenkel, M.; Glasner, A.; Sarig, S. Journal of Physical Chemistry 1980, 84, 507-510.

14. Poeppelmeier, K. R.; Hwu, S.-J. Inorganic Chemistry 1987, 26, 3297-3302.

15. Thiel, J. P.; Chiang, C. K.; Poeppelmeier, K. R. Chemistry of Materials 1993, 5, 297-304.

16. Fogg, A. M.; Freij, A. J.; Parkinson, G. M. Chemistry of Materials 2002, 14, 232-234.

17. Shen, C. H.; Liu, R. S.; Jang, L.-Y.; Lee, J. F.; Chen, J. M. Journal of the Chinese Chemical Society, 2002, 49, 841-850.

18. Lajavardi, M.; Kenny, D. J.; Lin, S. H. Journal of the Chinese Chemical Society 2000, 47, 1043-1053.

19. Lajavardi, M.; Kenny, D. J.; Lin, S. H. Journal of the Chinese Chemical Society 2000, 47, 1055-1063.

20. Lajavardi, M.; Kenny, D. J.; Lin, S. H. Journal of the Chinese Chemical Society 2000, 47, 1065-1075. 